\title{
Port choice in Brazil: a qualitative research related to in-depth interviews
}

\author{
Felipe Lobo Umbelino de Souza ${ }^{1 *} \mathbb{B}$, Cira Souza Pitombo ${ }^{1}$ and Dong Yang ${ }^{2,3}$
}

${ }^{*}$ Correspondence:

felipe.lobo@usp.br

${ }^{1}$ Department

of Transportation

Engineering, Engineering

School of São Carlos,

University of São Paulo, São

Carlos, São Paulo, Brazil

Full list of author information

is available at the end of the article

\begin{abstract}
The choice of port is one of the topics that most interest researchers. Port selection behaviour may vary depending on port user perspectives. Prior studies have attempted to determine user preferences for certain port choice factors, but there are only few studies in developing countries, such as Brazil, where there is a lack of studies on this topic. The objectives of this article are to analyse the port selection factors in Brazil for different port users, to discuss the implications for competitiveness among ports and to assist port service providers to formulate strategies. Identifying factors will help port service providers to develop strategies in the Brazilian market. The paper explores the case of the Southeast region port market in Brazil, based on data from the port sector and in-depth interviews with a representative selection of port users and specialists in the port sector. The results suggest that Brazilian Port Administrations need to adopt strategies aimed at increasing connections with the interior of Brazil, but they also need to adopt a highly market-based approach, communicating and synchronizing strategies with different public and private stakeholders.
\end{abstract}

Keywords: Port choice, Port competition, Brazilian shipping market, Port policy

\section{Introduction}

Many container ports have been developed around the world. Competition, however, creates a situation of excess capacity in the sector. Port competitiveness has been a fundamental issue in the container transport industry (Cho 2014). There are four main topics related to port competition analysis: (1) Port productivity and efficiency; (2) Port performance; (3) Port choice; and (4) Port competitiveness (Lagoudis et al. 2017). The port choice analysis is one of the topics that has attracted the most interest from researchers (Mennis et al. 2008).

Selecting a port is a difficult task. Shippers and carriers have several options. Each element included in supply chains must demonstrate the highest efficiency (Cepolina and Ghiara 2013). Port Authorities (PAs) are under constant fear of losing their customers due to changing requirements and priorities (Mittal and McClung 2016). Therefore, in order to maintain a competitive advantage, PAs must understand the factors that affect the port users' choices (Tiwari et al. 2003).

The port choice is not the result of a single agent (Martínez-Pardo et al. 2020). There are many decision makers who interact in the port system (Meersman et al.

(c) The Author(s), 2021. Open Access This article is licensed under a Creative Commons Attribution 4.0 International License, which permits use, sharing, adaptation, distribution and reproduction in any medium or format, as long as you give appropriate credit to the original author(s) and the source, provide a link to the Creative Commons licence, and indicate if changes were made. The images or other third party material in this article are included in the article's Creative Commons licence, unless indicated otherwise in a credit line to the material. If material is not included in the article's Creative Commons licence and your intended use is not permitted by statutory regulation or exceeds the permitted use, you will need to obtain permission directly from the copyright holder. To view a copy of this licence, visit http:// creativecommons.org/licenses/by/4.0/. 
2009). In container transport, four major categories are involved: port authorities, container terminals, shipping lines and cargo owners (Castelein et al. 2019).

Studies can be found in the literature examining the factors that influence port selection, especially in areas where there is significant competition (Murphy and Daley 1994). Port selection criteria have been reviewed in the literature (Martínez Moya and Feo Valero 2017), but they have a limited number of studies for developing countries, such as Brazil. Due to the lack of studies on ports and the relationship between different port users, there are some gaps related to the best strategies that the port sector should adopt in the Brazilian market to increase competitiveness.

Brazil's Gross Domestic Product (GDP) is estimated at \$ 1.87 trillion (the ninth largest in the world) and the value exported in 2018 reached \$ 242 billion, while the imported value reached $\$ 173$ billion (OEC 2020). The Brazilian port market is marked by the large number of ports. Despite this fact, the Port of Santos (São Paulo, Brazil) corresponds to $44 \%$ of the national market share. This market concentration in the Port of Santos has several effects for national logistics: (i) concentration of shipping lines in one port: the Port of Santos concentrates many maritime services; (ii) idleness of port terminals: terminals are more idle due to the lower number of ship calls; (iii) increased costs for logistics companies in the country: companies have fewer options for choosing ports, then they need to export or import through a port farther from their location.

Due to the importance of the theme for competitiveness, the objectives of this paper are: (i) to analyse the characteristics of the port selection factors in Brazil for different port users; (ii) to discuss the implications for competitiveness among ports in the region based on the different preferences of shippers and shipping lines; (iii) to assist port service providers, such as PAs and terminals, and to formulate strategies to increase port competitiveness.

The context of the southeast region port market was analysed. This article is based on four ports located in three different Brazilian states. This study focuses on the deep-sea part, excluding short-sea shipping, and analysing the container market. The survey included interviews with logistics managers, representatives of the four analysed ports, representatives from container shipping companies operating in Brazil, consultants, as well as university lecturers and researchers. The responses obtained in the interviews are analysed with port data (e.g., ship calls, infrastructure, consignment level) obtained from ANTAQ (2020) and Solve Shipping Intelligence (2020).

It is worth mentioning that this paper is the first stage of a study associated to port demand modelling in Brazil. The factor analysis will be used in a subsequent research step.

The remainder of the paper is structured as follows. The second section describes a Brazilian study case. "Port choice-A literature review" section analyses a literature review on port selection factors. The fourth section presents the research method. "Analysis and discussion of results" section carries out an analysis of preferences for choosing the port based on interviews and data analysis and discusses the impact of these preferences on ports. The last section draws the conclusions and suggestions are put forward for future studies. 


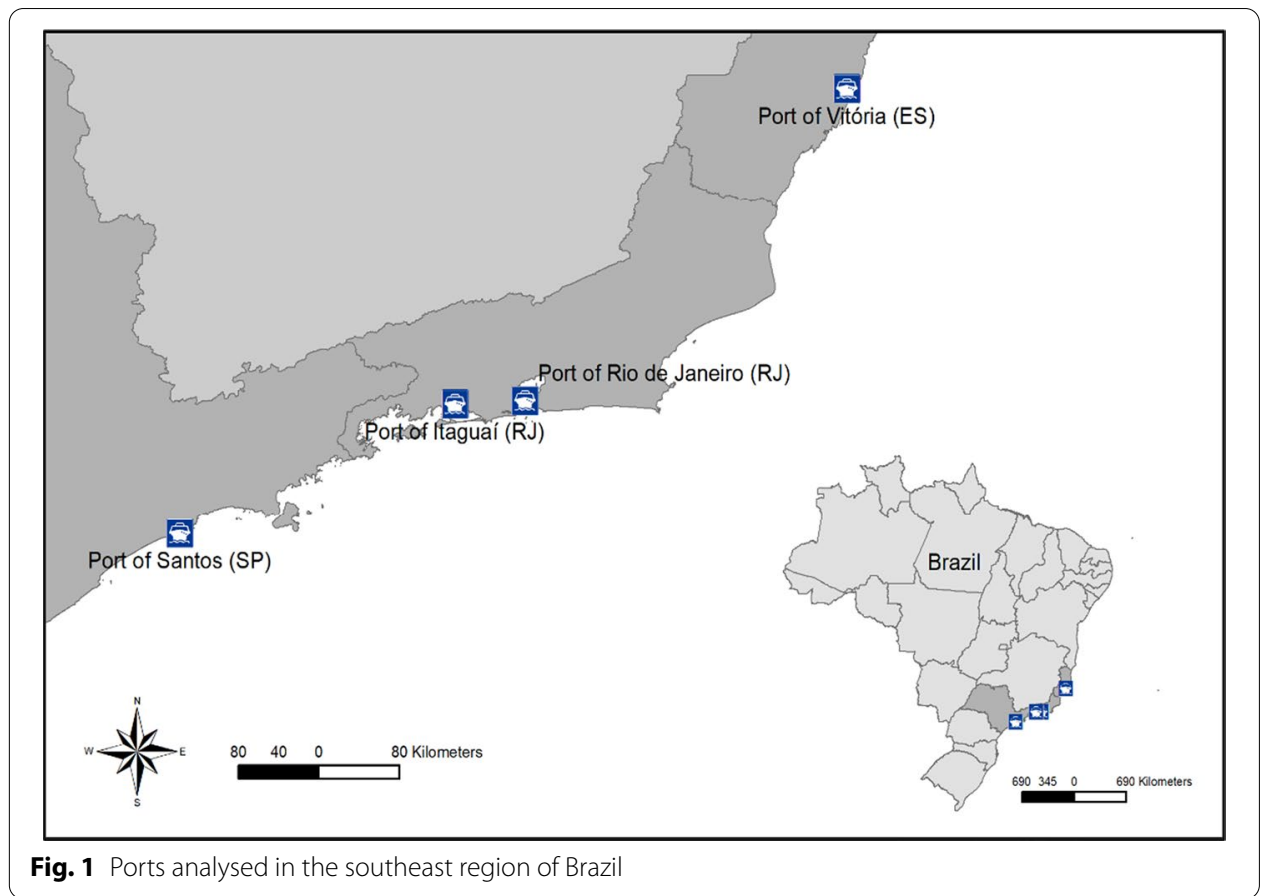

Table 1 Container handling in the Ports of Southeast Brazilian region

\begin{tabular}{lcc}
\hline Port (State) & Container (Thousand teu) & $\begin{array}{l}\text { National } \\
\text { market share } \\
(\%)\end{array}$ \\
\hline Santos (SP) & 3231.24 & 44.5 \\
Rio de Janeiro (RJ) & 372.83 & 5.13 \\
Itaguaí (RJ) & 253.99 & 3.50 \\
Vitória (ES) & 226.6 & 3.12 \\
\hline
\end{tabular}

Source: ANTAQ 2020

\section{Brazilian ports in the southeast region of Brazil: a brief description}

The context of four ports is analysed: (1) Port of Santos, located in the State of São Paulo (SP); (2) Port of Vitória, located in the State of Espírito Santos (ES); (3) Port of Rio de Janeiro, located in the State of Rio de Janeiro (RJ); (4) Port of Itaguaí, located in the State of Rio de Janeiro (RJ). The ports analysed have the greatest movement of containers in the region (ANTAQ 2020). Figure 1 shows the location of the analysed ports in the three coastal states in the southeast region (ES, RJ and SP).

The four ports are located in the southeast region of Brazil, where they compete in partially overlapping interior areas. The region has the largest port handling volume in Brazil, especially the Port of Santos. The Port of Santos is the main port in Brazil. Its area of economic influence concentrates more than 50\% of the GDP in Brazil (Table 1).

Table 2 shows the main information on the Port infrastructure detailed by container terminals. Port of Vitória has 1 container terminal (Vila Velha); Port of Rio has 2 terminals (ICTSI and Multiterminais); Port of Itaguaí has 1 terminal (Sepetiba Tecon) and Port of Santos has 3 terminals (Santos Brasil, DP World and BTP). 
Table 2 Port infrastructure detailed by terminals in the Ports of Southeast Brazilian region

\begin{tabular}{llllllr}
\hline Port & Terminal & Berths & $\begin{array}{l}\text { Draft } \\
\text { allowed } \\
(\mathbf{m})\end{array}$ & Max Loa $(\mathbf{m})$ & Total Area $\left.\mathbf{( m}^{\mathbf{2}}\right)$ & $\begin{array}{l}\text { Annual } \\
\text { Capacity } \\
\text { (teu) }\end{array}$ \\
\hline Vitória & Vila Velha & 2 & 10.7 & 244 & 103,000 & 353,257 \\
Rio de Janeiro & Multiterminais & 2 & 13.8 & 340 & 251,000 & $1,000,000$ \\
& ICTSI & 2 & 13.8 & 340 & 188,000 & 580,000 \\
Itaguaí & Sepetiba & 3 & 14.7 & 366 & 400,000 & 660,000 \\
Santos & Santos Brasil & 4 & 13.5 & 340 & 596,000 & $2,000,000$ \\
& DP World & 4 & 13.5 & 340 & 848,000 & $1,200,000$ \\
& BTP & 3 & 13.5 & 340 & 490,000 & $2,500,000$ \\
\hline
\end{tabular}

Source: ANTAQ (2020), Solve Shipping Intelligence (2020)

Comparing the analysed ports in this paper, the terminals at the Port of Santos stand out in terms of total area, annual capacity, and number of berths. Despite being the largest port complex in Latin America (Santos Port Authority 2021), the Port of Santos has limitations in terms of operational draft $(13.5 \mathrm{~m})$ and maximum length overall (LOA) (340 m). Conversely, the Port of Itaguaí has advantages in these characteristics, although it may have limitations in terms of capacity. The Port of Vitória has limitations mainly in terms of operational draft and maximum LOA.

\section{Port choice-A literature review}

There is a limited number of studies on port competition in Latin America and Africa. Asia has the most studies on port selection followed by the United States and Europe (Tiwari et al. 2003; De Langen 2007; Steven and Corsi 2012; Lagoudis et al. 2017). The number of studies on Brazilian ports in the literature is relatively low when compared to other regions (Galvão et al. 2013; Wanke and Barros 2016). Thus, identifying the factors that influence the selection of ports in Latin America, mainly in Brazil, helps to gain a better understanding of the port industry.

Researchers have used a variety of methods to analyse the port choice process (Malchow and Kanafani 2004; Tongzon and Sawant 2007; Onut et al. 2011; Lagoudis et al. 2017). Surveys and interviews have been adopted by most studies (Slack 1985; Murphy and Daley 1994; De Langen 2007; Panayides and Song 2012; Yang et al. 2016). Martínez Moya and Feo Valero (2017) highlighted that most articles analysed the issue using discrete choice models. The literature also presents articles that used qualitative techniques (Slack 1985; Hanelt and Smith 1987; Castelein et al. 2019).

There are no studies on port choice factors in Brazil in which users and specialists in the sector have participated. This gap in the literature emphasises the importance of the present study. For instance, Wanke and Falcão (2017) analysed cargo allocation in Brazilian ports using fuzzy logic. The study selected attributes based on factors presented in prior studies (distance to the port; degree of centrality; waiting time in queue time for ships; handling costs and shipment frequency). However, interviews conducted with different port users revealed factors that have not been sufficiently addressed in the literature: state taxes (for importers), risk of cargo theft when transporting goods to the port (for exporters). Exporters and importers did not present the same factors for the port selection process. Users perceive certain attributes differently (Cascajo et al. 2017), 
and according to Gohomene et al. (2016), the port selection decision may vary between geographic regions.

Understanding the existing motivators for choosing a port is important to inform policy decisions (O'Connor et al. 2020). Therefore, analysing the case of an important developing country such as Brazil, known for its problems related to planning and infrastructure, is important for formulating policies and guiding the private sector.

The relevant literature regarding port choice identifies multiple factors that influence port users (Tavasszy et al. 2011). Magala and Sammons (2008) argued that port users make port choice decisions differently and aim to achieve different objectives.

The reviewed literature reveals that the selection criteria for the container port and the results differ based on the perspective of the decision maker (Min and Park 2020). Table 3 summarises the factors in container port selection addressed in the literature. The previous literature is grouped according to the region of study, and separately presents the perspectives of different port users.

Port users think predominantly in financial terms. Shippers and forwarders seek to minimise their overall logistics costs (Meersman et al. 2010). The port that contributes to the cheapest supply chain is, in theory, the one most likely to be chosen. For shippers/ forwarders, the factors found in the literature can be varied: port location; port fees; transport costs to the port; frequency of ships; cargo loss and damage; service quality; efficiency; port equipment; port information services; size of the shipper.

Shipping lines also have their own considerations (Mulder and Dekker 2017). The literature highlighted different factors. Many of them are related to location, effectiveness and connectivity. The main factors found in the literature are: port location; ocean distance; port berth availability; port cargo volume; port costs, port services; port efficiency; physical and technical infrastructure; port hinterland transport connections. Table 3 summarizes some important findings.

\section{Methodological flowchart}

This section focuses on the analytical framework applied in this research. To define the factors of port choice in the region, qualitative research through interviews was performed to understand the perspectives. It is important to include an in-depth interview to obtain richer and more nuanced results to understand the sector (Holguín-Veras et al. 2013). If personal information, rather than generalised or normative views, is required, one-to-one depths may be more appropriate (Grosvenor 2000).

The Brazilian market is analysed in this paper based on the analytical structure presented in Fig. 2, following four steps. The starting point of the analytical framework was to identify the stakeholders: who chooses the port in Brazil? Shippers, forwarders and shipping lines have been identified as the major decision-makers (Aronietis et al. 2011). According to Talley and Ng (2013), there is no consensus on who should be considered the decision maker, and this may be due to the fact that most studies in the literature have analysed port choice by the shipping line and the shipper independently from each other.

Three categories of port users (shippers, forwarder and shipping lines) were considered in this paper. The categories were divided into two groups: (i) shippers and forwarders; and (ii) shipping lines. However, for shippers and forwarders, the study aimed to 


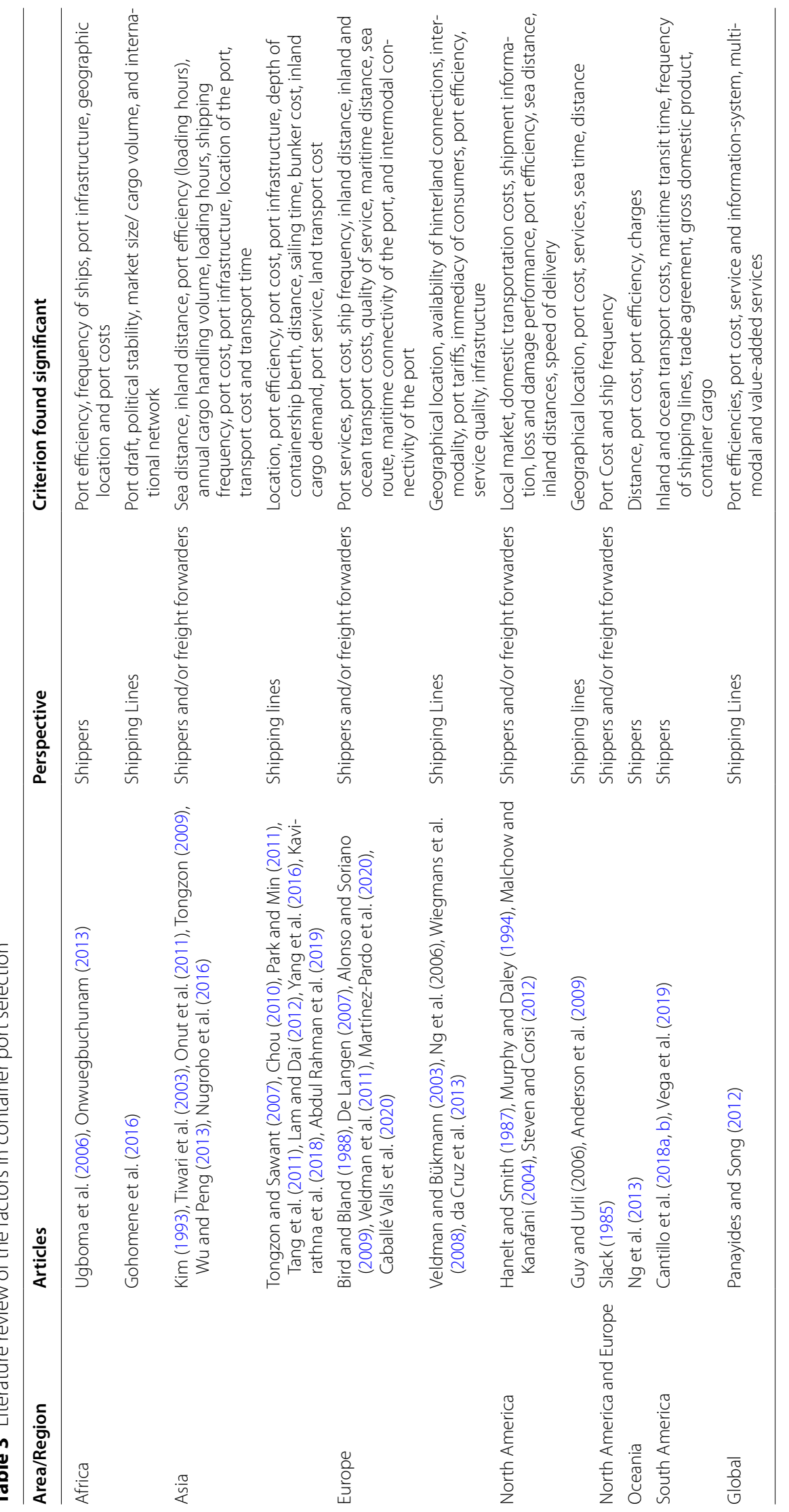




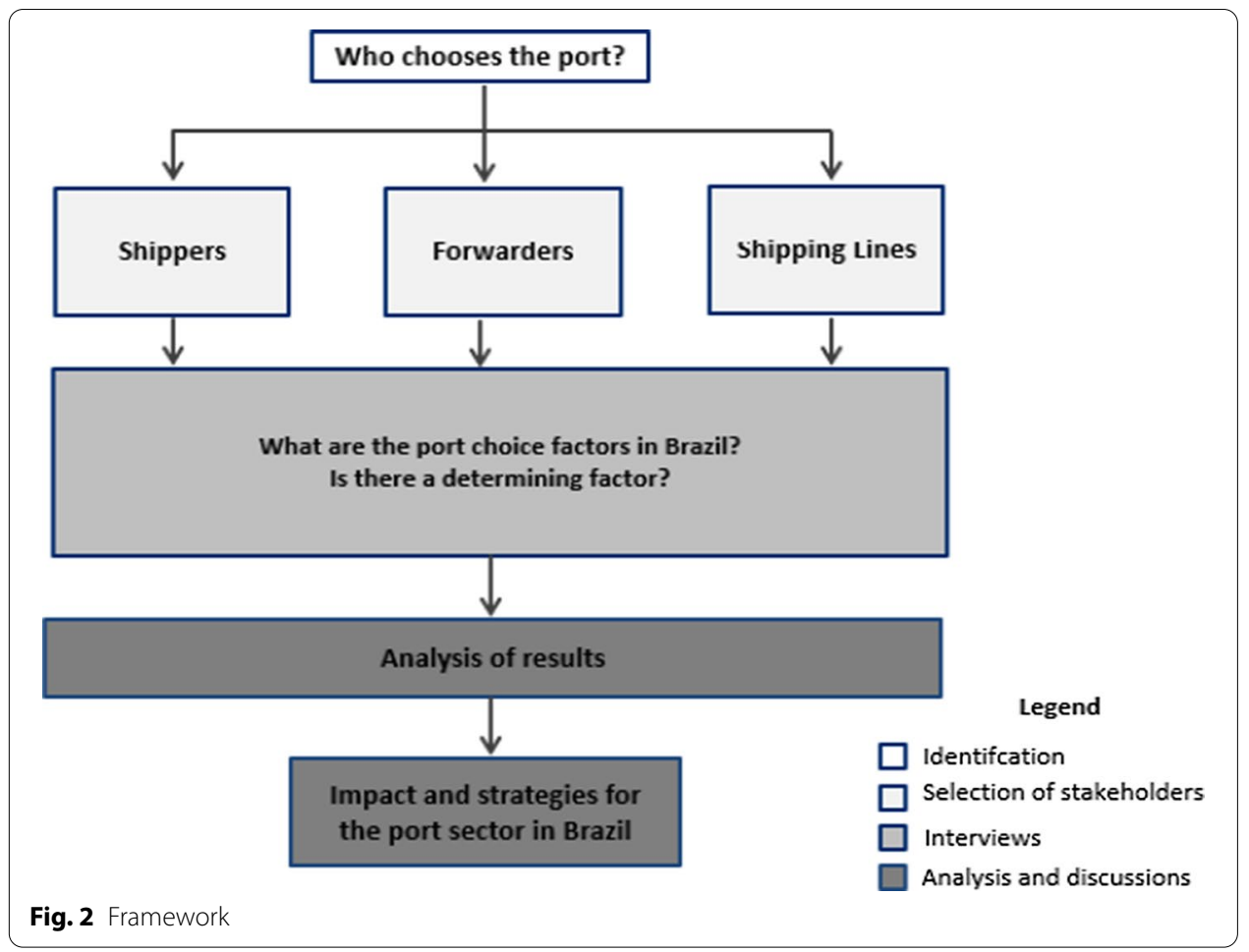

identify factors for export and import processes, which are considered when a shipper's/ forwarder's exports or imports are differentiated to understand the different process.

In the second step, respondents were selected based on the criterion that they should be directly involved in port choice decisions or knowledge in the port industry, resulting in respondents in management positions in commercial, strategic or research areas. Each interview lasted between one and three hours. The interviewees revealed factors based on their professional history or company perspective.

At the beginning of each interview (third step), there was a presentation of the research objectives. The interview had two pre-defined questions: (i) What are the port choice factors in Brazil? (ii) Is there a determining factor? These questions were used as a guide, not as a restriction. The interview gradually turned into a conversation with more questions and comments. Notes were taken during the interviews.

The revealed factors were compared with the literature and secondary data collected from the sector in sections "Shippers and forwarders" and "Shipping lines". The interviews sought to determine the most cited factors and were interrupted as new interviews started not revealing new factors/information. From January 2020 to June 2020, twenty-six interviews were conducted.

In the fourth step, responses were analysed to determine how port users depend on the port selection process. This dependence has an impact on the port sector. Section "Discussions on the impact for the port sector" presents discussions on the impact and policies for the analysed ports.

The qualitative data derived from interviews cannot be used for statistical analysis (Bengtsson 2016). Interviewing respondents from various types of stakeholder organisations is likely to produce contradictory views, but the interviews sought to analyse 


\begin{tabular}{|l|l|l|}
\hline \multicolumn{1}{|c|}{ EXPORT } & \multicolumn{1}{c|}{ IMPORT } \\
\hline $\begin{array}{ll}\text { - Ship Frequency } \\
\text { - Port Tariff (handling and storage) } \\
\text { - Land Transport Tariff } \\
\text { - Cargo Release Time } \\
\text { - Cargo Theft Risk } \\
\text { - Incidence of congestion }\end{array}$ & $\begin{array}{l}\text { - Ship Frequency } \\
\text { - Taxation (ICMS) } \\
\text { - Cargo Release Time } \\
\text { - Land Transport Tariff } \\
\text { - Port Tariff (handling and storage) } \\
\text { - Maritime Transport Tariff }\end{array}$ \\
\hline
\end{tabular}

different groups including consultants, as well as university lecturers and researchers to verify statements by industry companies. Representatives of the analysed ports also participated in the interviews to obtain a point of view from each terminal.

\section{Analysis and discussion of results}

The main discussions pointed out during the interviews are analysed in this section. In the first part, the perspective of shippers and forwarders is analysed. In the second part, the context of shipping lines is analysed. In Section "Discussions on the impact for the port sector", a discussion on the impact of these issues for the port sector is developed.

\section{Shippers and forwarders}

Twenty-three interviews were conducted to obtain port selection factors. The sample consisted of (13) logistical managers, (3) consultants, (4) representatives of the four analysed ports and (3) professors in the port area. The interviews aimed to identify the most important factors based on market experience or research, highlighting the context of the Brazilian port market, which may differ from the foreign market. The factors reported in Fig. 3 were the most cited during the interviews.

First, it should be noted that the study identified factors related to taxation (for importers), and cargo theft (for exporters) that are characteristics found in the Brazilian market and not highlighted in previous studies (factors highlighted in red in Fig. 3). Second, among the factors highlighted in the interviews, only two are considered to be in control of the port: Port Tariff and Cargo Release Time. The other criteria can be considered out of the control of the port. Martínez Moya and Feo Valero (2017) argue that the choice of port depends on factors under control such as efficiency or port fees. However, the port choice is also influenced by factors outside the control of the port, placing the port administration in a secondary role.

For exporters, it was stated that the most important issue is the synchronisation of the cargo (arrival of the container at the port to board the ship, with the shortest possible stay in the port). There is a concern to send the cargo as soon as possible, therefore ship calls and cargo release time are important.

For importers, this synchronisation is reduced, the ship arrives at the port, and the container is unloaded. The cargo remains in the port for days due to bureaucratic 


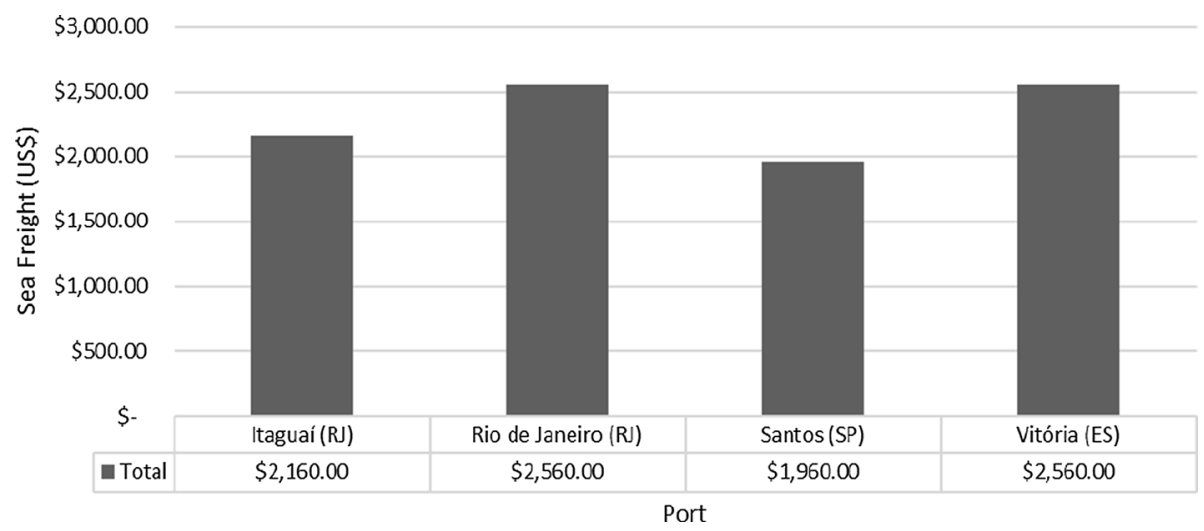

Fig. 4 Sea Freight Rate (US\$) for importing a 40 'container from Hong Kong to the analysed ports

issues. In addition, the tax on the value of the imported cargo influences the choice. Therefore, for importers, the choice is based on ship calls, taxation issues and cargo release time.

The Ship Frequency and Port Tariff (handling and storage) were factors highlighted by exporters and importers in the interviews and are in accordance with international literature. Regarding the tariff, the variable is often cited in studies in the area, but it should be noted that the importance attributed to the variable varies depending on the decision maker considered. Certain product categories such as coffee receives tariff exemptions from ports for exportation, as revealed in the interviews.

The Land Transport Tariff was also highlighted and is shown in the literature. The efficient access of a port to the interior is an essential determinant of competitiveness (Notteboom and Rodrigue 2005). Companies try to minimise the cost of transportation by negotiating with the transport company (Tiwari et al. 2003; Tongzon 2009; Steven and Corsi 2012; Ng et al. 2013).

Maritime Transport Tariff per container (US\$) for the importer was highlighted. According to the Incoterm FOB (Free on Board) model, one of the most used, the buyer (importer) is responsible for the shipment payment. In a study carried out in Colombia, Vega et al. (2019) indicate that this factor can have an impact on demand. The Port of Santos (SP) has greater availability of shipping lines and, consequently greater competition among shipping lines. This port has lower tariffs for transporting containers. It is worth noting that the price is negotiated in the North American currency, which makes the importer vulnerable to exchange rate variations. In periods when the dollar value is high, this factor has a greater weight in the port selection. Figure 4 shows the comparison of sea freight rate for a container originating from Hong Kong to Brazil.

Cargo Release Time: for both groups, this factor was highlighted. This factor is associated with the port's ability to release cargo more quickly, which is related to the efficiency of equipment, port infrastructure and also to bureaucratic processes in Brazil that delay the release of goods due to the high number of inspections. The dispatcher needs to communicate to several agencies that work in this area, often having to pass the same information on to different agencies. Thus, delays in release increases the storage cost for the company (CNI 2018). According to FIRJAN (2017), bureaucracy 


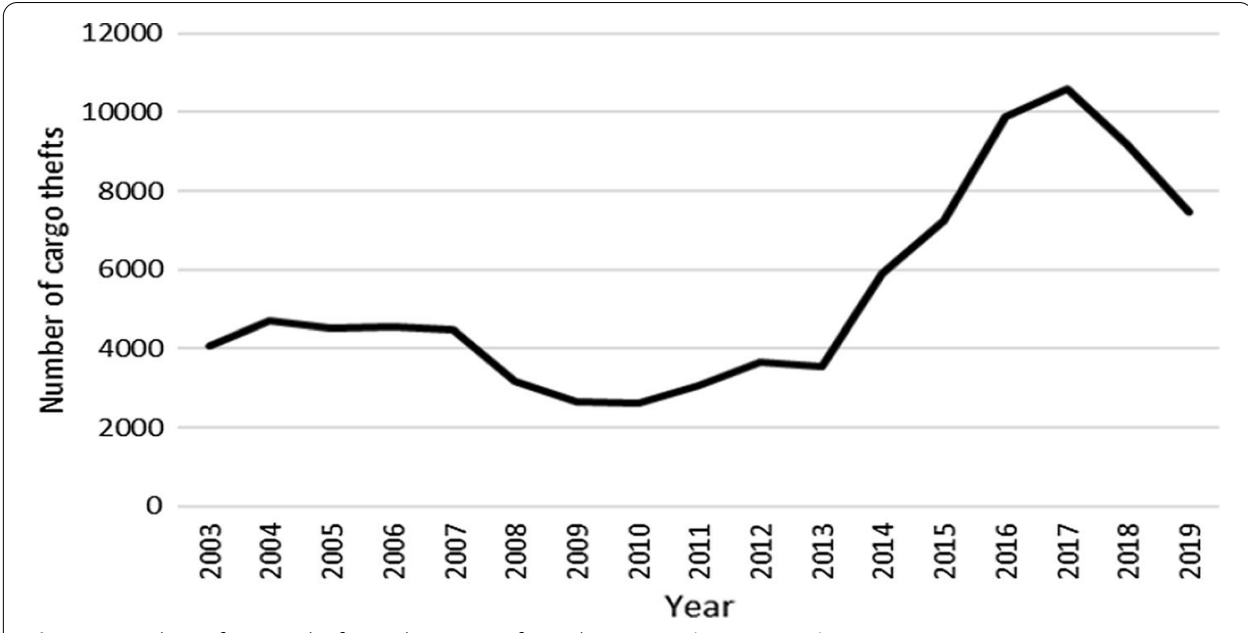

Fig. 5 Number of cargo thefts in the State of Rio de Janeiro (2003-2019)

negatively affects Brazilian companies that operate in international trade, in which Cargo Release is a critical issue, mainly for importers.

Cargo Theft Risk: this is an external factor for exporters, not highlighted in the literature, but which has an impact on cargo logistics in Brazil, especially in the city of Rio de Janeiro. In 2013, cargo theft cases in Rio de Janeiro increased significantly. In 2017, there was a record for cases of cargo theft, while in the following years the occurrences decreased. Figure 5 shows the number of cargo thefts in the State of Rio de Janeiro. It is noteworthy that this factor is related to the Cargo Transport to Rio de Janeiro and is a problematic factor for the port of that city. The main examples of countries at high risk of cargo theft are Brazil and Mexico (JCC Annual Cargo Forum 2017). In Brazil, the problem is the concentration of cases in the Southeast region (84.8\%) (ISP/ RJ 2019).

The main access routes to the city of Rio de Janeiro present greater insecurity for cargo transportation (ISP/RJ 2019). This insecurity can lead companies to divert cargo to other Ports (Santos- SP and Vitória-ES), as the high number of cases in the region raises costs (vehicle tracking, insurance and armed escort) (Portos e Navios 2017). The number of cases has decreased over the past two years, but companies have argued that the fear is still high, and this affects the port selection. This issue related to cargo theft on the roads and in the regions that access the port shows the dependence that the ports have on the public sector. The problem is not related to the port, but it raises doubts about measures that a port can take to mitigate insecurity.

Incidence of congestion in land access to the port: this is important for exporters, in which access to the port is a critical issue. Access time can hamper companies' plans to ship cargo for exports. This factor is related to the quality of land access to the port. Some ports, such as Santos, have automatic scheduling using a QR code to expedite entry to the port. The companies aim to synchronise their arrival at the port on the day of the ship's departure. Congestion hinders access and planning. In China, Tiwari et al. (2003) indicated that the number of TEUs handled in a port indicates congestion and has a negative impact on shippers' decisions. 


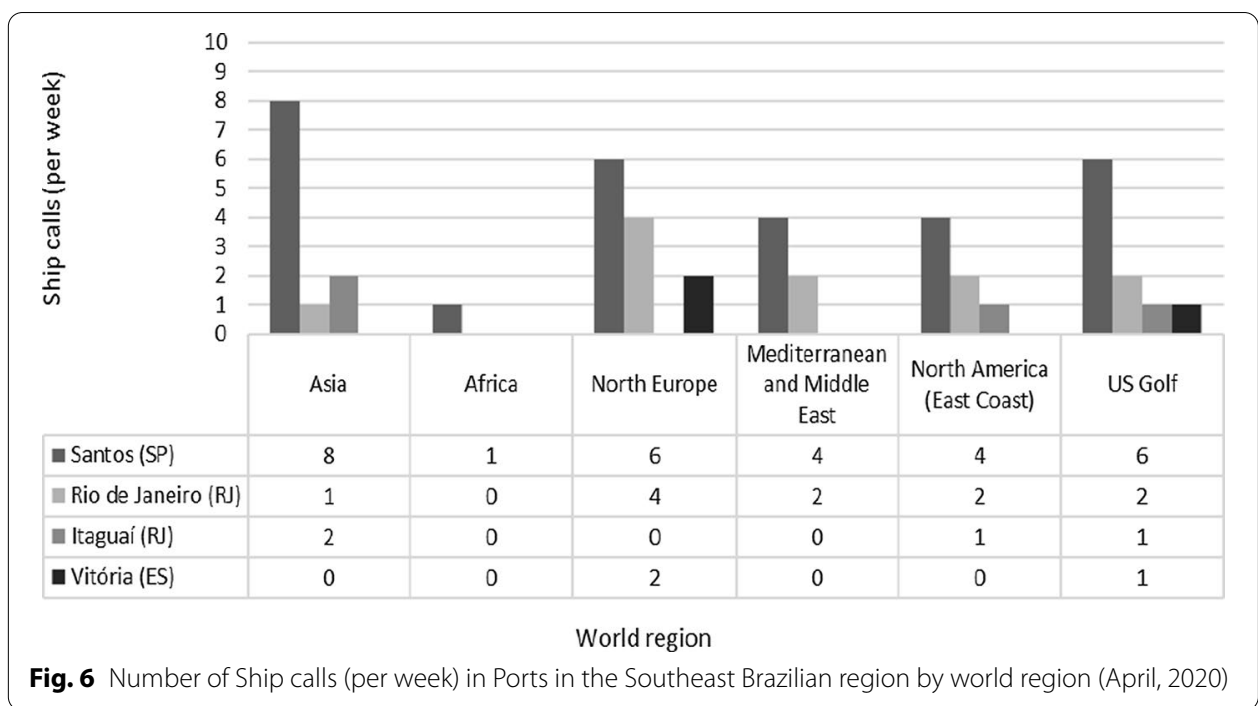

Taxation $\left(\mathrm{ICMS}^{1}\right)$ : this is a factor that is often mentioned for imports. Port states grant tax benefits to attract taxpayers and encourage investment in their territories. In recent years, the state of Santa Catarina has created measures to stimulate the economy. One of the measures was granting tax benefits to import companies established in the state. These measures have the main characteristic of reducing the ICMS.

The 1988 Constitution allowed the states to set ICMS rates on domestic operations and removed power from the Federal State to grant exemptions and rebates from the state tax (Alves 2001). However, this concession of tax benefits on imported products started the so-called "War of ports" in Brazil. This war is marked by fiscal benefits granted by the states that aim to have greater movement in their ports and, consequently a greater collection of taxes, but cause an imbalance in the port market (Lizote and Bidinha 2012). Companies from other states seek to import goods through ports in states where there are tax benefits.

Ship Frequency: During the interview, it was observed that this was the most prominent factor, and for most of the interviewees, the main criterion of choice. This variable was the one that many studies found as a determinant of the choice of port for shippers as it measures the frequency of maritime services in container ports (Ugboma et al. 2006; Tongzon 2009; Steven and Corsi 2012; Nugroho et al. 2016).

The ship calls at the port of Santos is higher than the other ports and this makes this port advantageous (Fig. 6).

Given the importance of the Ship Frequency factor for shippers/forwarders, some questions were asked: (i) How can the port increase the frequency of ships? (ii) What are the advantages of the Port of Santos compared to other ports? These questions led to the inclusion of an analysis on the shipping lines' perspective.

\footnotetext{
${ }^{1}$ ICMS: is the acronym for Tax on Circulation of Goods and Transportation and Communication Service. Imposto sobre Circulação de Mercadorias e Serviços (in Portuguese). ICMS is the main tax levied by the 26 Federal states and applies to: the movement of goods, the services of transportation between several States or municipalities.
} 
Table 4 Key findings about exporters and importers

\begin{tabular}{|c|c|c|}
\hline Type & Factor & Main findings \\
\hline \multirow[t]{6}{*}{ Export } & Ship Frequency & $\begin{array}{l}\text { The most cited factor. The factor alters the company's planning, as it affects } \\
\text { the immediacy of shipment to the destination and/or the storage time of } \\
\text { the container in the terminal }\end{array}$ \\
\hline & Port Tariff & $\begin{array}{l}\text { Tariff is related to the cost of moving the container at the terminal. The value } \\
\text { depends on the negotiation between the terminals and the companies }\end{array}$ \\
\hline & Land Transport Tariff & This is related to the cost of transporting the company's cargo to the port \\
\hline & Cargo Release Time & $\begin{array}{l}\text { This depends on the efficiency of the terminals in releasing and moving the } \\
\text { container for export }\end{array}$ \\
\hline & Cargo Theft Risk & This depends on the incidence of cargo theft on the access roads to the port \\
\hline & Incidence of congestion & $\begin{array}{l}\text { This affects the planning of companies and is related to the time it takes the } \\
\text { vehicle to access the terminal }\end{array}$ \\
\hline \multirow[t]{6}{*}{ Import } & Ship Frequency & $\begin{array}{l}\text { The most cited factor. The factor alters the company's planning because it } \\
\text { affects the transit time of imports }\end{array}$ \\
\hline & Taxation (ICMS) & $\begin{array}{l}\text { Tax on the value of imported cargo. The rate depends on the State of Brazil } \\
\text { where the port is located }\end{array}$ \\
\hline & Cargo Release Time & $\begin{array}{l}\text { This factor depends on the efficiency of the terminals in releasing and moving } \\
\text { the container for import. Bureaucracy in the release of products can affect } \\
\text { the time of release for import }\end{array}$ \\
\hline & Land Transport Tariff & $\begin{array}{l}\text { This factor is related to the cost of transporting the company's cargo from the } \\
\text { port to the company }\end{array}$ \\
\hline & Port Tariff & $\begin{array}{l}\text { This is related to the cost of handling and storage of the container at the } \\
\text { terminal. The value depends on the negotiation between the terminals and } \\
\text { companies }\end{array}$ \\
\hline & Maritime Transport Tariff & $\begin{array}{l}\text { Sea freight rate in relation to the transport of containers from a country of } \\
\text { origin to Brazil }\end{array}$ \\
\hline
\end{tabular}

Table 4 summarizes the main findings related to the factors highlighted by exporters and importers in the port selection process. Analysing the factors between exporters and importers, some common factors can be observed. Ship calls were the most cited factor for both groups in the port choice process. Port Tariff, Land Transport Tariff and Cargo Release Time were also cited as important for both groups.

However, some different factors can be observed for each group. For instance, for exporters, the interviews indicated a concern about the risk of cargo theft in transport to the port and the incidence of land access congestion in the port region in the port choice process. In fact, these factors can hinder the planning of companies as occurs with congestion, or even monetary losses and loss of the company's merchandise with the occurrence of thefts. For importers, the interviews revealed concerns about taxing the value of the imported product and the sea freight rate, referring to maritime transport. Sea freight is quoted in American currency, which leads to a situation in which the importer depends on the exchange rate. The tax rate influences the cost of companies in the import process.

Some factors cited by companies during the interviews were similar to factors investigated by studies carried out in regions with developing economies such as Brazil: frequency of ships, port efficiency, port costs, maritime transport tariff.

According to Table 3, in the African region, Ugboma et al. (2006) and Onwuegbuchunam (2013) analysed factors such as Port efficiency, frequency of ships, port infrastructure, geographic location and port costs. In South America, Cantillo et al. 
Table 5 Factors most highlighted by shipping lines

\begin{tabular}{ll}
\hline Factors & Main explanation \\
\hline $\begin{array}{l}\text { Volume of cargo (export and import) } \\
\text { Strategy }\end{array}$ & $\begin{array}{l}\text { State of São Paulo has the advantage (largest GDP in Brazil) } \\
\text { The hinterland of the Port of Santos (location closest to } \\
\text { the largest industrial park in Brazil) favours a higher } \\
\text { frequency of ships } \\
\text { Supply of berths and greater depth }\end{array}$ \\
\hline
\end{tabular}

(2018a, b) and Vega et al. (2019) studied inland and ocean transport costs, maritime transit time, frequency of shipping lines and trade agreements.

Cantillo et al. (2018a, b) used official records of imports and exports in Colombia to estimate port choice models. The results indicated that the existence of a trade agreement between Colombia and the country of origin/destination and maritime transit time are important factors in port choice. However, in this study conducted in the southeast of Brazil, these factors were not mentioned. On the other hand, Taxation and Risk of cargo theft were factors cited as important by companies in Southeast Brazilian region, while these factors were not cited by studies carried out in Colombia.

\section{Shipping lines}

Currently, the Ports of Brazil have the performance of several container shipping companies in long-distance shipping (Maersk, Hamburg Sud, MSC, Happag Lloyd, CMA CGM, Cosco Shipping, Evergreen, Marfret, One, Grimaldi, PIL, Hyundai and Yang Ming).

To analyse the selection factors, three representatives from container shipping companies operating in Brazil were interviewed. Table 5 presents the factors most highlighted by the container shipping companies. In general, the shipping companies stated that the volume of cargo is a fundamental factor in the decision of including a port on the maritime route. According to the interviews, a hub port concentrates captive cargo in quantity. The Port of Santos has this fixed asset as an advantage compared to its competitors in imports from the State of São Paulo.

The Geoeconomics of the Port of Santos (location closest to the largest industrial park, the state with the highest GDP and population) favours more ship calls due to greater cargo handling. This situation can be compared to the situation of the North Sea Ports, in Europe, as is the example of the Port of Rotterdam, which has a good location close to large production/consumption centres (Moreira 2009). The shipping lines seek to reach the largest economic areas (Park and Min 2011; Wiegmans et al. 2008).

Therefore, the hinterland of the Port of Santos is the fundamental factor that makes this port the first candidate for a hub port in Brazil. The Port of Santos has extensive areas of influence in the States of São Paulo, Minas Gerais, Rio de Janeiro, Mato Grosso and Mato Grosso do Sul. Santos has influences where competing ports also have them (UNB 2012). The port activity corresponds to the dynamics of the hinterlands to which they are connected (He et al. 2019).

Nevertheless, $60 \%$ of the ships in operation on the Brazilian coast have a maximum draft equal to or greater than $14 \mathrm{~m}$. On the Asian route, half of the ships have a maximum draft equal to or greater than $15 \mathrm{~m}$ (Solve Shipping Intelligence 2020). This fact increases pressure on ports due to limited depth. It is noteworthy that the Port of Santos, 

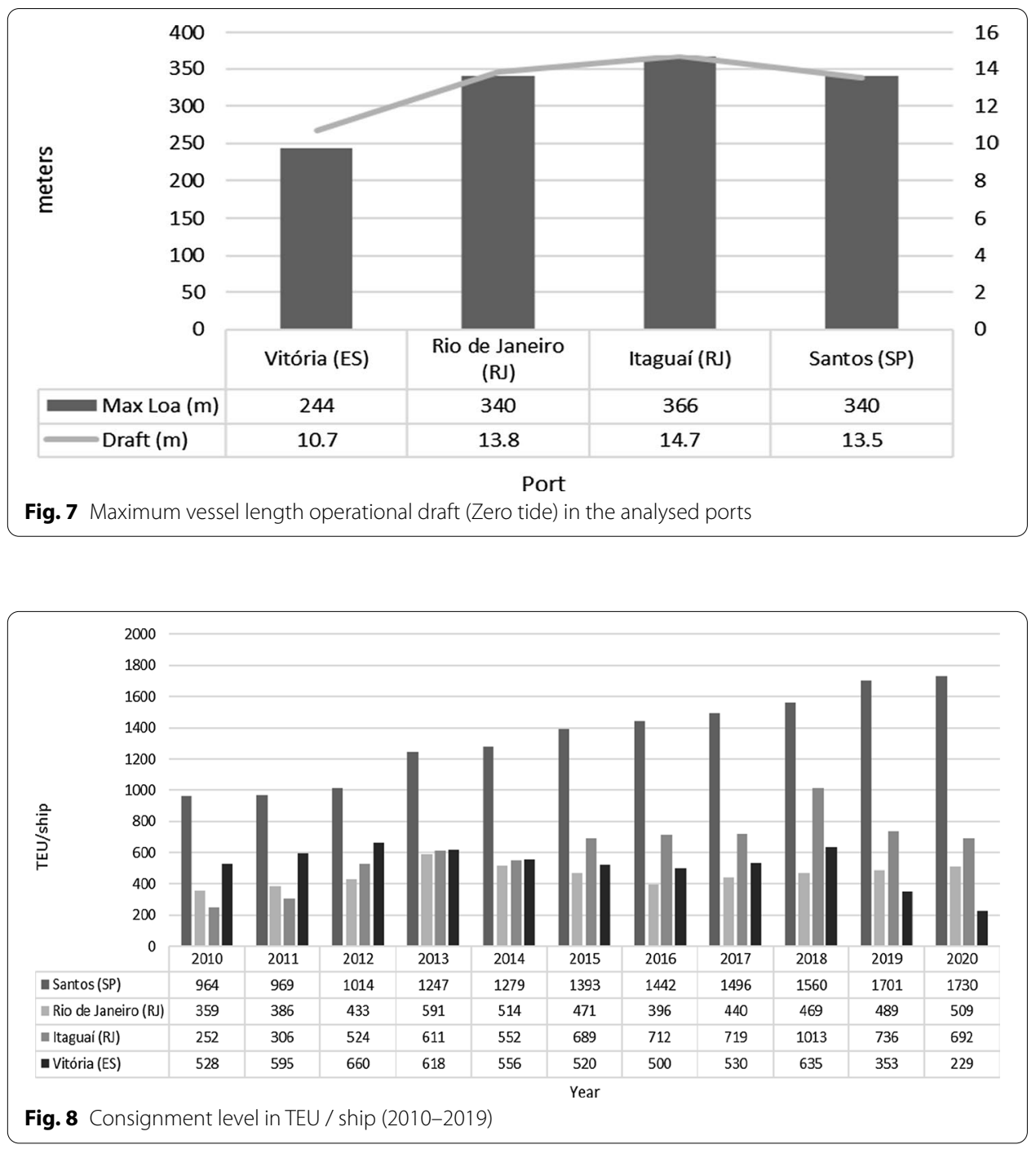

has limitations of operational draft $(13.5 \mathrm{~m})$. The Port of Itaguaí allows an operational draft of $14.7 \mathrm{~m}$. According to one interviewee, Santos in certain periods, is unable to meet the demand due to problems of access to large ships or congestion. Thus, the Port of Itaguaí is used to reduce demand in Santos (Fig. 7).

Despite the problem of the Port of Santos, interviews with representatives from container shipping companies showed that draft is important, but it should be noted that the increase in the size of ships causes greater pressure to fill the ship at the terminals. Thus, Santos has the great advantage of offering a higher level of consignment (TEU/ ship) (Fig. 8). Pragmatically, "cargo attracts ships and that is Santos' advantage". The level of consignment increases in Santos with the use of larger ships and the greater concentration of maritime lines. The port of Itaguai ${ }^{2}$ also shows an increase, as this port has the vocation of being a hub port. 


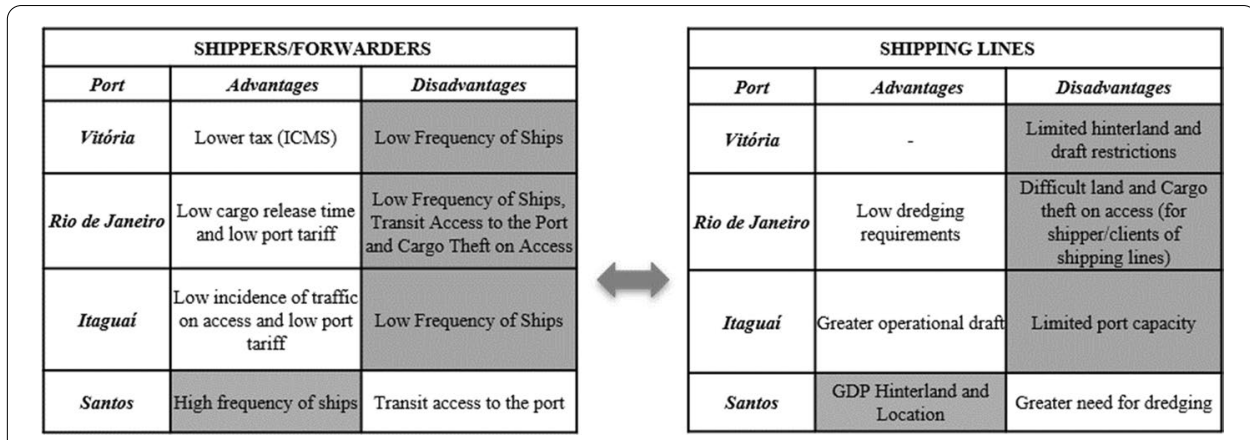

Fig. 9 Advantages and disadvantages in the perspective of shippers/forwarders and shipping lines

\section{Discussions on the impact for the port sector}

At the end of the interviews, the respondents were asked to cite advantages and disadvantages in choosing a particular port. The relationship between the perspectives is shown in Fig. 9 and highlighted:

i. Santos: the main advantage was the higher frequency of ships (from the shippers' point of view) while the shipping lines pointed out that this port has the best location/GDP Hinterland. This shows the relationship between port calls and GDP Hinterland.

ii. However, it can be observed that Santos, despite being the main port in the country, has draft limitations. In East Asia, the hub port choice is analysed by Tai and Hwang (2005), who emphasise the handling efficiencies and drafts as the main internal factors of ports.

iii. Rio de Janeiro: shippers declared traffic and cargo theft at access as a disadvantage, and shipping companies declare the same as a disadvantage for their customers. Cargo theft is a feature of Brazil not highlighted in the port choice literature.

iv. Vitória: has an advantage, especially for imports, by offering a lower tax (ICMS). State tax is not a factor highlighted by prior studies.

v. Vitória and Itaguaí: shippers state that the disadvantages are the low frequency of ships, while the shipping lines pointed out problems of capacity and limited hinterland. This again shows the influence of the ocean carriers.

As ship calls are an important factor for shippers and they are controlled by the shipping lines, the position of the port as a monopolistic cargo operator in a given region is reduced. In this scenario, the following questions were asked: (i) What are the impacts for ports in Brazil? (ii) What are the strategies for ports to compete more efficiently?

In recent years, container shipping companies have restructured and reformed their shipping alliances (Yang et al. 2011), which significantly improves their bargaining power towards ports and terminal operators (Liu et al. 2020). The increase in the market power and the logistics of transporting the containers, marked by using large ships, result in a reduced number of hub ports. The capital intensity of these large ships forces them to limit their calls to some hub ports (Shanghai, Singapore, Hong Kong and Rotterdam), from where large volumes of containers are consolidated or sent later by smaller vessels for regional ports (Yang et al. 2018; Haralambides 2019; Parola et al. 2019). 
Table 6 Long Distance and Cabotage in Brazil

\begin{tabular}{|c|c|c|c|c|}
\hline & \multicolumn{2}{|l|}{ Long Distance } & \multicolumn{2}{|c|}{ Cabotage \& Mercosul } \\
\hline & December 2008 & December 2019 & December 2008 & December 2019 \\
\hline Services & 43 & 19 & 7 & 9 \\
\hline $\begin{array}{l}\text { Nominal Capacity } \\
\text { (TEU) }\end{array}$ & 108,405 & 113,802 & 7000 & 23,130 \\
\hline Biggest Ship & Rio Class (5900 TEU) & $\begin{array}{c}\text { Kota Pemimpin } \\
(11,923 \mathrm{TEU})\end{array}$ & $\begin{array}{l}\text { Aliança Ipanema } \\
\text { (2230 TEU) }\end{array}$ & $\begin{array}{l}\text { Monte Sarmiento (5500 } \\
\text { TEU) }\end{array}$ \\
\hline
\end{tabular}

Source: Solve Shipping Intelligence 2020

This implementation has effects on all maritime trade, via a cascade effect: due to the new larger ships in the main trades, the ships that were previously used on the commercial lines of the Far East-Europe are replaced and transferred to secondary lines of lower volume. This is the case of the East Coast of South America (Merk 2018). Currently, Brazilian ports are preparing to receive New Panamax ships, with 366 m (LOA).

In this constant process of increasing the dimensions of the ships, if the terminals want to continue to manage their share of services, they will have to continuously invest to provide the necessary means to make their facilities capable of receiving large ships (increased depth, larger cranes, increased cargo handling capacity). Ports that do not make these improvements will lose their market share (Wray 2017).

In Brazil, cabotage (coastal navigation) and feeder operations grew from seven to nine services, a 29\% increase in the demand for docking windows in the period of 2008-2019. Conversely, the number of long-distance services off the Brazilian coast has halved and decreased from 43 to 19 services. In 2008, the ship with the highest nominal capacity in Brazil (5,905 TEUs) was $286 \mathrm{~m}$ (LOA), $40 \mathrm{~m}$ wide and $13.2 \mathrm{~m}$ draft. This ship profile has almost doubled in size in ten years. In 2019, the ship Kota Pemimpin, had 11,923 TEUs of nominal capacity, $330 \mathrm{~m}$ (LOA), $48.3 \mathrm{~m}$ wide and $15 \mathrm{~m}$ draft (Table 6) (Solve Shipping Intelligence 2020).

As a result, there is a general reduction in the number of port calls at Brazilian ports. In December 2008, the number of port calls in the country was 222; in December 2019, the number reduced to 166 (Solve Shipping Intelligence 2020). In the Southeast, the Ports of Santos and Rio de Janeiro had a 32\% reduction in the period. Itaguaí had a reduction of $50 \%$, while Vitória had a reduction of $17 \%$ (Fig. 10).

The smaller quantity of services decreased the demand for berths, increasing the idle capacity. Consequently, the competition for services between terminals and the need for investments to receive larger ships increased. As revealed during interviews with port managers, the use of larger ships raises pressure at port terminals. The port terminals must constantly show evidence to shipping companies that the terminals have a high and stable level of consignment. Large investments are needed to improve container terminals. However, it is not simple for container ports to have sufficient cargo volumes in containers to justify massive investments.

From the perspective of shippers/forwarders in the region, the lower frequency of ships in Brazil significantly impacts exporter and importer logistics. Companies have fewer options for weekly calls. This strategy of shipping lines, as observed in the interviews, affects the transit time of imports. The Port of Santos has a greater presence of 


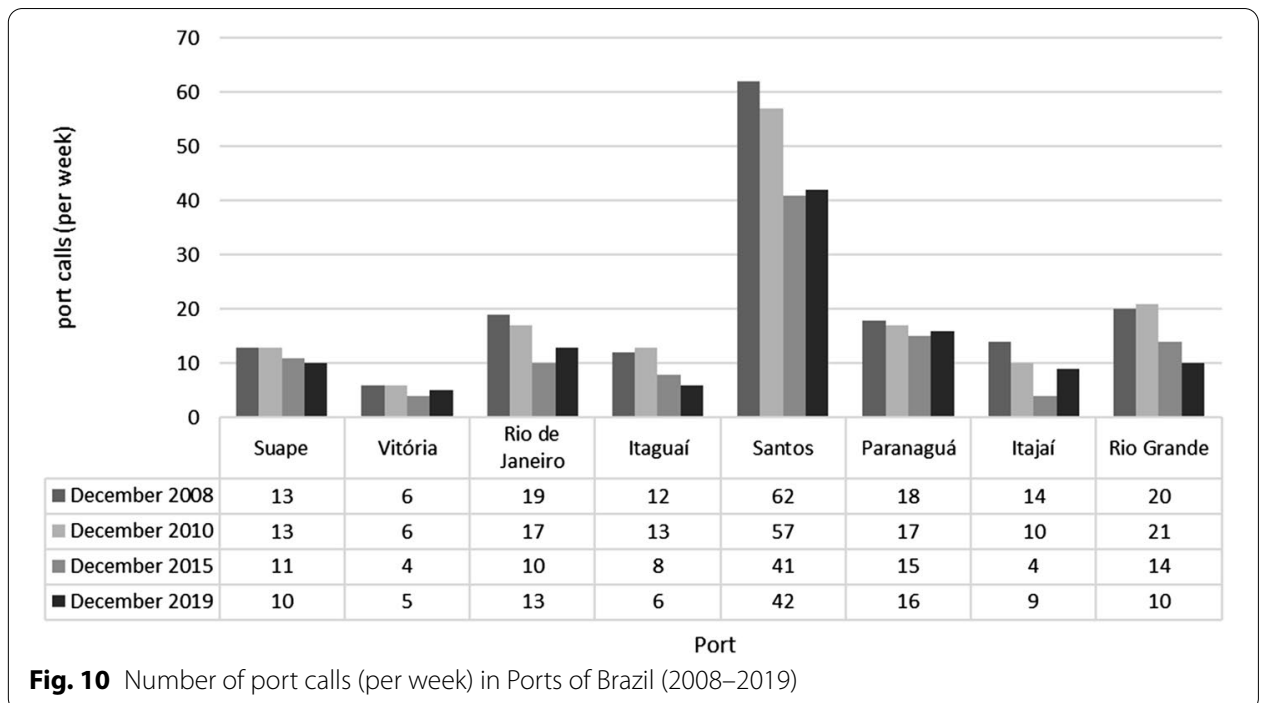

maritime lines, which leads companies to choose this port. Regarding exports, as the Port of Santos has a higher frequency of ships, companies choose this port for reasons of immediacy for shipment to the destination and/or to reduce the storage time of the container. Ports with less frequency can cause a longer storage time of the cargo that awaits the ship for boarding, consequently increasing the cost (port tariff) of the company. As highlighted by port managers, few companies have an export and import volume capable of negotiating and determining the port choice. The shipping market is fragmented, and the choices are conditioned to the port call schedules of the ocean carriers.

For efficient strategies, it should be noted that PAs generally concentrate on development in the port region. Traditionally, PAs have prioritised investment in port infrastructures, aiming to attract maritime lines. Thus, the maritime lines were considered the main customers of the port (Tongzon 2009; Malchow and Kanafani 2004). However, PAs need to become active outside the port area and academic research has begun to analyse this shift in focus towards a supply chain perspective (Robinson 2002). Based on this supply chain perspective, scholars have begun to argue that PAs need to expand their scope and contribute to the connection between ports and the interior (Van der Horst and De Langen 2008; Notteboom et al. 2017; Zhang et al. 2019).

An important strategic issue may be related to the price policy. PAs can subsidise the land side, charging higher port fees to shipping lines and invest part of these resources in rail access to reduce the cost of domestic transportation (Van den Berg and De Langen 2011). There are different forms of policies implemented in practice that the port may seek to adopt to maintain a balance of interests between different users (Fig. 11) $(\mathrm{Qu}$ et al. 2017). The viability of strategies should be analysed later in Brazil to identify the potential for conflict between ports.

Moreover, the factors revealed during the interviews imply that PAs in Brazil need to adopt more targeted strategies than simply seeking to increase connections with the interior. For example, PAs need to adopt a highly market-based approach, communicating and synchronising strategies with different public and private parties. Among the factors highlighted in Fig. 3, most are not controlled by ports, which requires the 


\begin{tabular}{|l|}
\hline \multicolumn{2}{|c|}{ For Shippers } \\
\hline - Provide subsidy to the transport \\
company \\
- Toll exemption for trucks with \\
containers arriving at the port \\
- Build a collection and \\
distribution corridor por point and \\
- Provide tax rebate policies from \\
the starting poing \\
preferential tax and \\
- Subsidizing port fees and \\
terminal handling charges \\
\hline
\end{tabular}

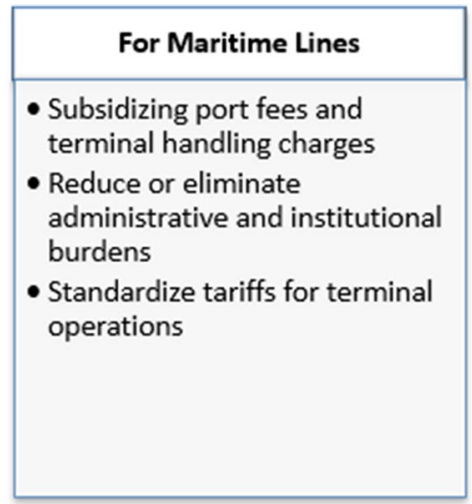

Fig. 11 Implementation of the subsidy policy for port customers

Table 7 Practical strategies for the identified factors

\begin{tabular}{|c|c|c|}
\hline Factors & Agents/players & Practical strategies \\
\hline Ship calls & Container shipping companies & $\begin{array}{l}\text { Alliances to encourage an increase in ship calls } \\
\text { at the port }\end{array}$ \\
\hline Land Transport Tariff & Shippers/Freight forwarders & $\begin{array}{l}\text { Preferential tariff structure or subsidies to reduce } \\
\text { land transport tariff }\end{array}$ \\
\hline Cargo Release Time & Public agencies & $\begin{array}{l}\text { Reduce cargo release time, especially in the } \\
\text { import process }\end{array}$ \\
\hline Risk of cargo theft & Security area & $\begin{array}{l}\text { Reduce the cases of cargo theft during the trans- } \\
\text { port to the port }\end{array}$ \\
\hline Incidence of congestion & Municipal / state administration & $\begin{array}{l}\text { Carry out works that can reduce the incidence of } \\
\text { congestion }\end{array}$ \\
\hline Taxation (ICMS) & Federal government & $\begin{array}{l}\text { Define import taxes-ICMS—-so that market } \\
\text { values do not distort competition }\end{array}$ \\
\hline Maritime Freight Transport & Shippers/Freight forwarders & $\begin{array}{l}\text { Subsidize sea freight to reduce import costs for } \\
\text { importers }\end{array}$ \\
\hline
\end{tabular}

synchronization of PAs with different agents/players such as: (i) container shipping companies; (ii) Shippers/Freight forwarders; (iii) Public agencies; (iv) security area; (v) municipal/state administration; (vi) Federal government. Table 7 describes a series of practical strategies that PAs can adopt with different agents/players to improve their competitiveness for each identified factor during the interviews.

\section{Conclusion}

This paper presented an ongoing study that sought to identify factors related to the choice of port in the Brazilian context to identify possible attributes for the development of a study in the area of demand modelling for ports in the Southeast region of Brazil. This qualitative study presented choice factors and discussions that will be analysed later through quantitative methods. The growing competitive environment of ports in Brazil requires correct planning of port development to offer appropriate strategies to the market.

The study identified factors related to taxation and cargo theft that are characteristics presented in the Brazilian market and not highlighted by the international literature. Part 
of the identified factors is outside the port administration, which makes the position of the port more complex, and requires greater communication between public and private stakeholders and the port sector to identify strategies to increase competitiveness.

The paper presents interesting theoretical questions for future research. The geographical position of the Port of Santos is advantageous and causes a concentration of ship calls. However, Santos has problems related to dredging and in the future, this fact may limit the port with the arrival of larger ships. This leads to questions about which ports will be hubs in Brazil in the long term. With the arrival of larger ships of the New Panamax class, what will be the impacts on the Brazilian port sector?

The results of the interviews also reveal an interesting relationship. For shippers, the ship calls are the most important port choice factor, while for the shipping lines, the concentration of cargo is essential. Therefore, cargo attracts ships, and ships attract more cargo to the port. This relationship leads to questions about what the efficient measures for a port are to remain competitive. Identifying the interests of these stakeholders is important for modelling demand.

The challenge of port policy in Brazil is to balance the interests of different port customers. Analysing the impacts of increasing calls from large vessels is an important strategy for ports, because it could help them take more effective actions on how to expand their port infrastructure and productivity, but also determine tariff strategy ports that can be adopted to serve shippers/forwarders and shipping lines to attract more cargo and ships.

Abbreviations

ES: Espírito Santo (State); GDP: Gross domestic product; ICMS: Tax on Circulation of Goods and Transportation and Communication Service; LOA: Length overall; PA: Port authority; RJ: Rio de Janeiro (State); SP: São Paulo (State); TEU: Twentyfoot equivalent Unit.

Acknowledgements

The authors would like to thank Alexandre Leal and Leandro Barreto.

Authors' contributions

All authors contributed to the $1 \mathrm{st}, 2 \mathrm{nd}, 3 \mathrm{rd}$, 4th and 6 th. FS contributed to the 5 th section (conducting interviews). The authors read and approved the final manuscript.

\section{Funding}

CAPES.

Availability of data and materials

All data used on the paper is made available in the manuscript.

\section{Declarations}

Competing interests

Authors declare having no financial and non-financial competing or conflict of interest.

Author details

${ }^{1}$ Department of Transportation Engineering, Engineering School of São Carlos, University of São Paulo, São Carlos, São Paulo, Brazil. ${ }^{2}$ Department of Logistics and Maritime Studies, The Hong Kong Polytechnic University, Kowloon, Hong Kong Special Administrative Region, Hong Kong. ${ }^{3}$ Shipping Research Centre, The Hong Kong Polytechnic University, Kowloon, Hong Kong Special Administrative Region, Hong Kong.

Received: 29 March 2021 Accepted: 18 August 2021

Published online: 28 August 2021

References

Abdul Rahman NS, Notteboom T, Rahmatdin MS, Othman MK (2019) Port choice by intra-regional container service operators: an application of decision-making techniques to liner services between Malaysian and Other Asian Ports. Asian J Ship Logist 35(4):181-193 
Alonso L, Soriano J (2009) Port selection from a hinterland perspective. Marit Econ Logist 11(3):260-269

Alves MAS (2001) Guerra fiscal e finanças federativas no Brasil: o caso do setor automotivo. Universidade Estadual de Campinas, Instituto de Economia, Campinas, Dissertação (Mestrado em Economia)

Aronietis R, Van de Voorde E, Vanelslander T (2011) Competitiveness determinants of some European ports in the containerized cargo market. BIVEC/GIBET Transport Research Day, University Press, Namur.

Anderson CM, Opaluch JJ, Thomas A (2009) The demand for import services at US Container Ports. Marit Econ Logist 11(2):156-185

ANTAQ (2020) Anuário Estatístico. Available in: http://web.antaq.gov.br/ANUARIO/

Bengtsson M (2016) How to Plan and Perform a Qualitative Study Using Content Analysis Nursing plus Open 2:8-14

Bird J, Bland G (1988) Freight forwarders speak: the Perception of Route Competition via Seaports in the European Communities Research Project. Part 1. Marit Policy Manag 15(1):35-55

Brooks MR, Pallis AA (2008) Assessing port governance models: process and performance components. Marit Policy Manag 35(4):411-432

Button K, Chin A, Kramberger T (2015) Incorporating subjective elements into liners'seaport choice assessments. Transport Pol 44:125-133

Caballé Valls J, de Langen PW, García Alonso L, Vallejo Pinto JÁ (2020) Understanding port choice determinants and port hinterlands: findings from an empirical analysis of Spain. Marit Econ Logist 22(1):53-67

Cantillo J, Cantillo V, Arellana J (2018) Modelling with joint choice of ports and countries of origin and destination: application to Colombian ports. Maritime Pol Manag 45:6, 720-738

Cascajo R, Garcia-Martinez A, Monzon A (2017) A Stated preference survey for estimating passenger transfer penalties: design and application to Madrid. Eur Transp Res Rev 9:42

Cepolina S, Ghiara H (2013) New trends in port strategies. Emerging role for ICT infrastructures. Res Transp Bus Manac 8:195-205

Chou C (2010) AHP model for the container port choice in the multiple-ports region. J Mar Sci Technol 18(2):221-232

Cho HS (2014) Determinants and effects of logistics costs in container ports: the transaction cost economics Perspective. Asian J Ship Logist 30(2):193-215

Cantillo V, Visbal J, Arellana J (2018b) Analysis on the determinants of shipment size and type-of-truck choices using a discrete-continuous hybrid model. Int J Ship Transp Logist 10(4):406-428

Castelein RB, Geerlings H, Van Duin JHR (2019) Divergent effects of container port choice incentives on users' behavior. Transp Policy 84:82-93

CNI (2018) Os custos e encargos dos órgãos anuentes no comércio exterior brasileiro. Confederação Nacional das Indústria

da Cruz MRP, Ferreira JJ, Azevedo SG (2013) Key factors of seaport competitiveness based on the stakeholder perspective: an Analytic Hierarchy Process (AHP) model. Marit Econ Logist 15(4):416-443

De Langen P (2007) Port competition and selection in contestable hinterlands: the case of Austria. Eur J Transp Infrastruct Res $7(1): 1-14$

FIRJAN (2017) Diagnóstico do Comércio Exterior do Estado do Rio. Diagnósticos e Mapeamentos Setoriais. Sistema FIRJAN

Galvão CB, Robles LT, Guerise LC (2013) The Brazilian seaport system: a post-1990 institutional and economic review. Res Transp Bus Manag 8:17-29

Gohomene DA, Yang ZL, Bonsal S, Maistralis E, Wang J, Li KX (2016) The attractiveness of ports in West Africa: some lessons from shipping lines' port selection. Growth Chang 47(3):416-426

Grosvenor T (2000) Qualitative Research in the Transport Sector. Resource paper for the Workshop on Qualitative/Quantitative Methods, Proceedings of an International Conference on Transport Survey Quality and Innovation. May 24-30 1997 (Grainau, Germany), Transportation Research E-Circular, Number E-C008, August

Haralambides HE (2019) Gigantism in container shipping, ports and global logistics: a time-lapse into the future. Marit Econ Logist 21:1-60

He D, Sun Z, Gao P, Lau YY (2019) Spatial-temporal evolution of the port-hinterland relationship: a case study of the Midstream Yangtze River. China Growth Change 50(3):1043-1061

Hanelt RL, Smith DS (1987) The dynamics of west coast container port competition. J Transp Res Forum 28(1):82-91 Holguín-Veras J, Wang C, Hodge S, Wojtowicz J, Rothbard S, Browne M (2013) The New York City off-hour delivery project: lessons for city logistics. In: Taniguchi E, Thompson RG (eds) Innovations in city logistics. Elsevier, Bali, pp 36-48

ISP/RJ (2019). Dossiê Roubos de Carga 2019. Instituto de Segurança Pública/RJ

Lam J, Dai J (2012) A decision support system for port selection. Transp Plan Technol 35(4):509-524

JCC Annual Cargo Forum (2017) Global Cargo Risk Outlook 2017. Lloyd's Old Library. Access: January 2020

Kavirathna C, Kawasaki T, Hanaoka S (2018) Transshipment hub port selection criteria by shipping lines: the case of hub ports around the bay of Bengal. J Shipp Trd 3:4

Kim H-S (1993) Decision Components of Shippers' Port Choice in Korea. Korea Maritime Institute, Seoul

Lagoudis IN, Theotokas I, Broumas D (2017) A literature review of port competition research. Int J Shipp Transp Logist 9:724

Lizote SA, Bidinha ER (2012) Guerra Fiscal dos Portos: um Estudo sobre o Impacto da Unificação do ICMS Interestadual em 4\% para Produtos Importados no Estado de Santa Catarina. In: Simposio de Excelência em Gestão e Tecnologia, 12, 2012. Itajaí: UNIVALI, Resende

Liu Z, Yang D, Ng YNE (2020) A competitive analysis of port of Hong Kong: from external to internal. J Shipp Trd 5:7

Magala M, Sammons A (2008) A new approach to port choice modelling. Marit Econ Logist 10:9-34

Malchow M, Kanafani A (2004) A Disaggregate analysis of port selection. Transp Res E 40(4):317-337

Martínez-Pardo A, Orro A, Garcia-Alonso L (2020) Analysis of port choice: a methodological proposal adjusted with public data. Transp Res A 136:178-193

Martínez Moya J, Feo Valero M (2017) Port choice in container market: a literature review. Transp Rev 37(3):300-321

Meersman H, Van de Voorde E, Vanelslander T (2010) Port competition revisited. Rev Bus Econ Lit 55(2):210-232 
Meersman H, Van de Voorde E, Vanelslander T (2009) The economic fabric of ports. In: Meersman H, Van de Voorde E, Vanelslander T (eds) Future challenges for the port and shipping sector. Informa, London, pp 89-107

Mennis E, Platis A, Lagoudis I, Nikitakos N (2008) Improving port container terminal efficiency with the use of Markov theory. Marit Econ Logist 10(3):243-257

Merk O (2018). The container port of Buenos Aires in the mega-ship era. Discussion Paper, International Transport Forum, Paris

Mittal N, McClung D (2016) Shippers' changing priorities in port selection decision - a survey analysis using analytic hierarchy process (AHP). JTransp Res Forum 55(3)

Min H, Park BI (2020) A two-dimensional approach to assessing the impact of port selection factors on port competitiveness using the Kano model. Marit Econ Logist 22:353-382

Moreira AS (2009) Metodologia aplicada para obter um sistema de indicadores de porto concentrador de carga. Escola Politécnica, Universidade de São Paulo, São Paulo, Tese de Doutorado

Mulder J, Dekker R (2017) Optimisation in container liner shipping. In: Geerlings H, Kuipers B, Zuidwijk R (eds) Ports and networks. Strategies, operations, and perspectives. Routledge, London and New York, pp 181-203

Murphy PR, Daley JM (1994) A comparative analysis of port selection factors. Transp J 34(1):15-21

Ng ASF, Sun D, Bhattacharjya J (2013) Port choice of shipping lines and shippers in Australia. Asian Geogr 30(2):143-168

Nir A-S, Lin K, Liang G-S (2003) Port choice behaviour-from the perspective of the shipper. Marit Policy Manag 30(2):165-173

Notteboom T, Rodrigue J-P (2005) Port regionalization: towards a new phase in port development. Marit Policy Manag 32(3):297-313

Nugroho MT, Whiteing A, De Jong G (2016) Port and inland mode choice from the exporters' and forwarders' perspectives: Case study - Java. Indonesia. Res Transp Bus Manag 19:73

OEC (2020). The Observatory of Economic Complexity: OEC. Available: https://oec.world/en/profile/country/bra

Onut S, Tuzkaya UR, Torun E (2011) Selecting container port via a fuzzy ANP-based approach: a case study in the Marmara Region, Turkey. Transpt Policy 18(1):182-193

Onwuegbuchunam DE (2013) Port selection criteria by shippers in Nigeria: a discrete choice analysis. Int J Ship Transp Logist 5(4-5):532-550

O'Connor E, Hynes S, Vega A, Evers N (2020) Examining demand and substitutability across terminals in a gateway port network: a discrete choice model of Irish ports. Case Stud Transp Policy 8(2):322-332

Park B, Min H (2011) The selection of transshipment ports using a hybrid data envelopment analysis/analytic hierarchy process. J Transp Manag 22(1):116-131

Parola F, Pallis A, Song DW (2019) Shipping and port marketing: policy and strategy. Transp Policy 84:24-26

Panayides PM, Parola F, Lam JSL (2015) The effect of institutional factors on Public-Private Partnership success in ports. Transp Res Part A 71:110-127

Panayides P, Song D-W (2012) Determinants of users' port choice. The Blackwell Companion to Maritime Economics, pp 599-622

Portos e Navios (2017) Roubo de cargas leva empresários a trocar o porto do Rio por Santos e Vitória. Available: https:// www.portosenavios.com.br/noticias/portos-e-logistica/39243-roubo-de-cargas-leva-empresarios-a-trocar-o-portodo-rio-por-santos-e-vitoria

Qu C, Wang GWY, Zeng Q (2017) Modelling port subsidy policies considering pricing decisions of feeder carriers. Transp Res E: Logist Transp Rev 99:115-133

Robinson R (2002) Ports as elements in value-driven chain systems: the new paradigm. Marit Policy Manag 29(3):241-255

Santos Port Authority (2021) Complexo Portuário de Santos. Available: http://www.portodesantos.com.br/conhe ca-o-porto/o-porto-de-santos/

Slack B (1985) Containerization, inter-port competition and port selection. Marit Policy Manag 12(4):293-303

SOLVE Shipping Intelligence (2020) Análise Estatística. Available in: http://solveshipping.com/

Song D-W, Yeo K-T (2004) A competitive analysis of Chinese container ports using the analytic hierarchy process. Marit Econ Logist 6(1):34-52

Steven AB, Corsi TM (2012) Choosing a port: An analysis of containerized imports into the US. Transp Res E: Logist Transp $\operatorname{Rev} 48(4): 881-895$

Tongzon JL, Sawant L (2007) Port choice in a competitive environment: from the shipping lines' perspective. Appl Econ 39(4):477-492

Veldman S, Garcia L, Vallejo JA (2011) Determinants of container port choice in Spain. Marit Policy Manage 38(5):509-522

Tai H, Hwang C (2005) Analysis of hub port choice for container trunk lines in East Asia. J Eastern Asia Soc Transp Stud 6:907-919

Talley WK, Ng M (2013) Maritime transport chain choice by carriers, ports and shippers. Int J Prod Econ 142(2):311-316

Tang LC, Low JM, Lam SW (2011) Understanding port choice behaviour-A network perspective. Netw Spat Econ 11(1):65-82

Tavasszy LA, Minderhoud M, Perrin JF, Notteboom T (2011) A strategic network choice model for global container flows: specification, estimation and application. J Transp Geogr 19:1163-1172

Tiwari P, Itoh H, Doi M (2003) Shippers' port and carrier selection behaviour in China: a discrete choice analysis. Marit Econ Logist 5(1):23-39

Tongzon J (2009) Port choices and freight forwarders. Transp Res E 45(1):186-195

Veldman S, Garcia-Alonso L, Vallejo-Pinto JA (2013) A port choice model with logit models: a case study for the Spanish container trade. Int J Ship Transp Logist 5(4/5):373-389

Ugboma C, Ugboma O, Ogwude I (2006) An analytic hierarchy process (AHP) approach to port selection decisionsEmpirical evidence from Nigerian ports. Marit Econ Logist

UNB (2012) Avaliação da Concorrência na prestação de Serviços Portuários. Universidade de Brasilia, Centro De Excelência Em Regulação De Mercado

Van der Horst MR, De Langen PW (2008) Coordination in hinterland trans- port chains: a major challenge for the seaport community. Marit Econ Logist 10:108-129 
Van den Berg R, de Langen PW (2011) Hinterland strategies of port authorities: a case study of the port of Barcelona. Res Transp Econ 33(1):6-14

Vega L, Cantillo V, Arellana J (2019) Assessing the impact of major infrastructure projects on port choice decision: the Colombian case. Transp Res A: Policy Pract 120:132-148

Veldman SJ, Bükmann EW (2003) A model on container port competition: an application for the West European container Hub-ports. Marit Econ Logist 5:3-22

Wanke P, Barros C (2016) New evidence on the determinants of efficiency at Brazilian ports: a bootstrapped DEA analysis. Int J Shipp Transp Logist 8(3):250-272

Wanke P, Falcão B (2017) Cargo allocation in Brazilian ports: an analysis through fuzzy logic and social networks. J Transport Geogr 60:33-46

Wiegmans BW, Van Der Hoes A, Notteboom TE (2008) Port and terminal selection by deep sea container operators. Marit Policy Manag 35(6):517-534

Wray S (2017) White Paper: Impact of the Drive for the Economies of Scale on Container Terminals. WSP

Wu Y, Peng C (2013) A container port choice model for Pearl River Delta region in South China. Soc Behav Sci 96:1839-1852

Yang D, Jiang L, Ng AKY (2018) One belt one road, but several routes: a case study of new emerging trade corridors connecting the far East to Europe. Transp Res A: Policy Pract 117:190-204

Yang J, Wang GW, Li KX (2016) Port choice strategies for container carriers in China: a case study of the Bohai Bay Rim port cluster. Int J Ship Transp Logist 8(2):129-152

Yang D, Liu M, Shi X (2011) Verifying liner shipping alliance's stability by applying core theory Res. Transp Econ 32(1):15-24

Zhang Q, Zheng S, Geerlings H, Makhloufi A (2019) Port governance revisited: how to govern and for what purpose? Transpt Pol 77:46-57

\section{Publisher's Note}

Springer Nature remains neutral with regard to jurisdictional claims in published maps and institutional affiliations.

\section{Submit your manuscript to a SpringerOpen ${ }^{\odot}$ journal and benefit from:}

- Convenient online submission

Rigorous peer review

- Open access: articles freely available online

- High visibility within the field

Retaining the copyright to your article

Submit your next manuscript at $\gg$ springeropen.com 